\title{
An Evaluation of the Effects of Well Construction Materials and Ground-Water Sampling Equipment on Concentrations of Volatile Organic Compounds
}
T. L. Liikala
D. S. Daly
A. P. Toste

August 1988

Prepared for the U.S. Department of Energy under Contract DE-AC06-76RLO 1830

Pacific Northwest Laboratory Operated for the U.S. Department of Energy by Battelle Memorial Institute 


\section{DISCLAIMER}

This report was prepared as an account of work sponsored by an agency of the United States Government. Neither the United States Government nor any agency thereof, nor Battelle Memorial Institute, nor any or their employees, makes any warranty, expressed or implied, or assumes any legal liability or responsibility for the accuracy, completeness, or usefulness of any information, apparatus, product, or process disclosed, or represents that its use would not infringe privately owned rights. Reference herein to any specific commercial product, process, or service by trade name, trademark, manufacturer, or otherwise does not necessarily constitute or imply its endorsement, recommendation, or favoring by the United States Government or any agency thereof, or Battelle Memorial Institute. The views and opinions of authors expressed herein do not necessarily state or reflect those of the United States Government or any agency thereof, or Battelle Memorial Institute.

\section{PACIFIC NORTHWEST LABORATORY operated by BATTELLE MEMORIAL INSTITUTE for the UNITED STATES DEPARTMENT OF ENERGY under Contract DE-AC06-76RLO 1830}

\begin{tabular}{|c|c|}
\hline \multicolumn{2}{|c|}{ Printed in the United States of America } \\
\hline \multirow{2}{*}{\multicolumn{2}{|c|}{$\begin{array}{c}\text { Available from } \\
\text { National Technical Information Service }\end{array}$}} \\
\hline & \\
\hline \multirow{2}{*}{\multicolumn{2}{|c|}{$\begin{array}{c}\text { United States Department of Commerce } \\
5285 \text { Port Royal Road } \\
\text { Springfield, Virginia } 22161\end{array}$}} \\
\hline & \\
\hline \multirow{2}{*}{\multicolumn{2}{|c|}{$\begin{array}{l}\text { NTIS Price Codes } \\
\text { Microfiche A01 }\end{array}$}} \\
\hline & \\
\hline \multicolumn{2}{|c|}{ Printed Copy } \\
\hline & Price \\
\hline Pages & Codes \\
\hline $001-025$ & $\mathrm{~A} 02$ \\
\hline 026-050 & $\mathrm{A} 03$ \\
\hline $051-075$ & A04 \\
\hline $076-100$ & $\mathrm{~A} 05$ \\
\hline $101-125$ & $A 06$ \\
\hline $126-150$ & A07 \\
\hline $151-175$ & $\mathrm{~A} 0 \mathrm{~B}$ \\
\hline $176-200$ & $\mathrm{~A} 09$ \\
\hline $201-225$ & A010 \\
\hline $226-250$ & A011 \\
\hline $251-275$ & A012 \\
\hline $276-300$ & A013 \\
\hline
\end{tabular}


PNL -6585

UC-11

AN EVALUATION OF THE EFFECTS OF WELL CONSTRUCTION MATERIALS AND GROUND-WATER SAMPLING EQUIPMENT ON CONCENTRATIONS OF VOLATILE ORGANIC COMPOUNDS

T. L. Liikala

D. S. Daly

A. P. Toste

August 1988

Prepared for the U.S. Department of Energy under Contract OE-ACO6-76RLO 1830

Pacific Northwest Laboratory Richland, Washington 99352 


\section{SUMMARY}

In 1985, the Pacific Northwest Laboratory conducted a study on groundwater samples collected from the 300 Area of the Hanford Site, which is located in southeastern Washington. The purpose of the study was to evaluate how well construction materials and ground-water sampling equipment affect measured concentrations of volatile organic compounds in the ground water.

Ground-water samples were collected in an area of known contamination from two monitoring wells. Sampling was conducted for a total of 4 weeks using three dedicated sampling devices. Each sample was analyzed for volatile organic content by gas chromatography with electron capture detection. The data were statistically analyzed to ascertain differences in concentrations of contaminants resulting from well construction materials and ground-water sampling equipment.

No statistically significant differences in concentrations of volatile organic compounds were found resulting from the well construction materials and ground-water sampling equipment. Analyses indicate a correlation between constituent concentration and sample date and, to a lesser degree, water table elevation. The range in concentrations during the study was greater than the differences caused by the two wells and three sampling devices. 


\section{CONTENTS}

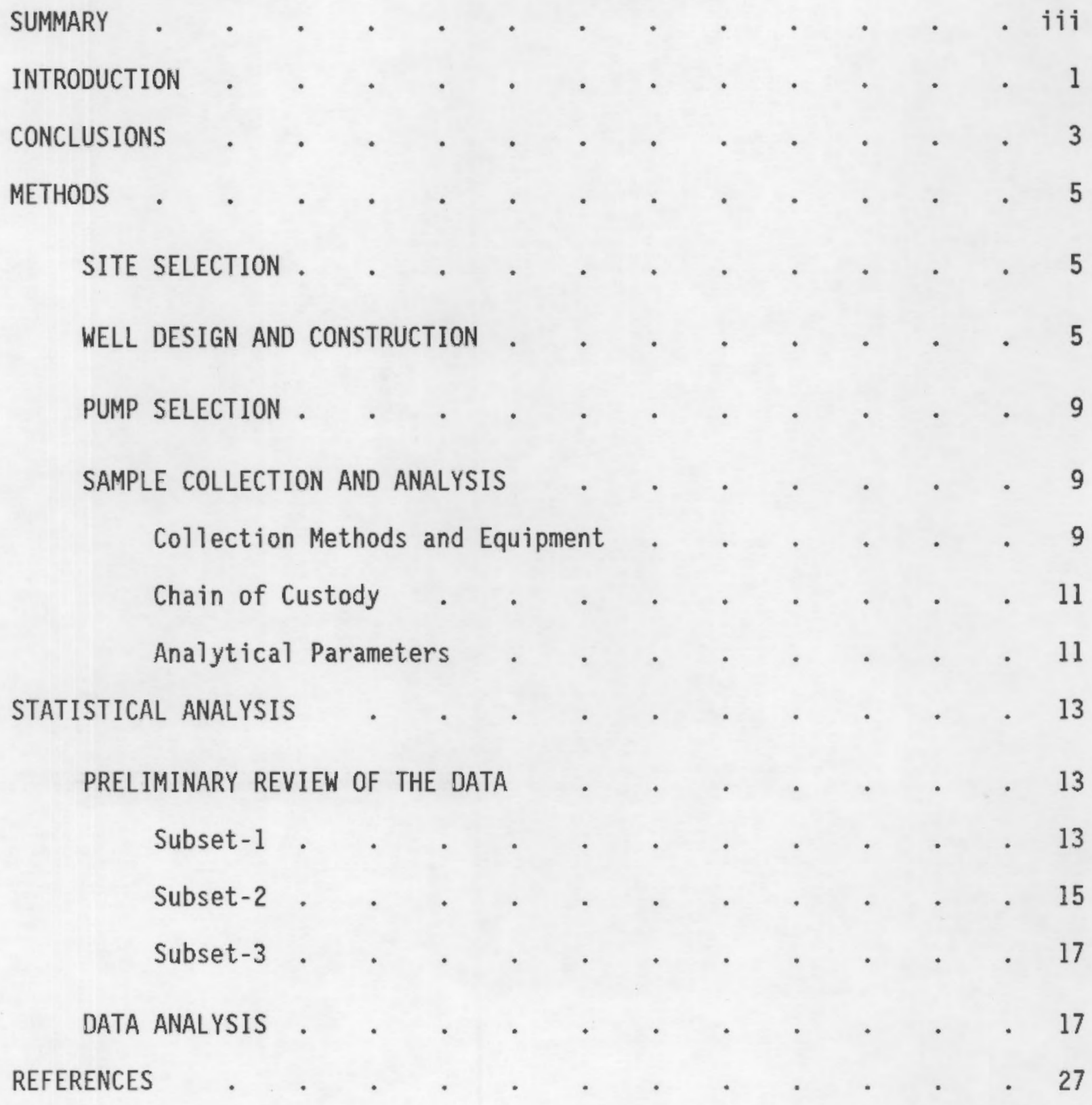




\section{$\underline{\text { FIGURES }}$}

1 Map Showing the Location of the Study Site . . . . . 2

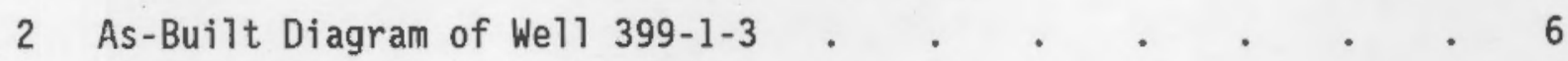

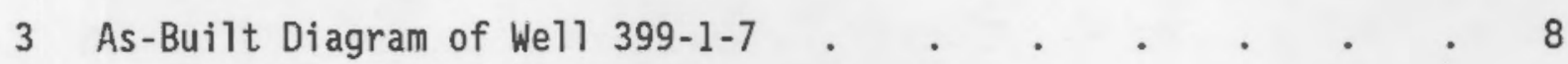

4 Hydrogeologic Log for Wells 399-1-3 and 399-1-7 . . . . 10

5 Comparison of PCE Concentrations in Samples Collected With the Bladder Pump in Well 399-1-7 and All Other Equipment in

Both Wells . . . . . . . . . . 16

6 PCE Concentrations for Each Sampling Date, We11, and Pump - . 21

7 TCA Concentrations for Each Sampling Date, We11, and Pump - . 21

8 TCE Concentrations for Each Sampling Date, Well, and Pump - 22

9 Chloroform Concentrations for Each Sampling Date, We11, and

Pump. . . . . . . . . . . . . 22

10 Multivariate Graph Matrix with Pearson Correlation

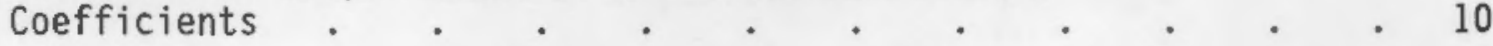

\section{$\underline{\text { TABLES }}$}

1 Analytical Data for the Equipment Evaluation Study . . $\quad 14$

2 Analytical Data in Subset-1 . . . . . . . . . . . . $\quad$. 15

3 Analytical Data in Subset-2 . . . . . . . . . . . 16

4 Analytical Data in Subset-3 . . . . . . . . . . . 17

5 Analysis of Variance Results . . . . . . . . . . . 23 


\section{INTRODUCTION}

Since 1944, operations at the Hanford Site, located in southeastern Washington, have generated large volumes of hazardous chemical and radioactive wastes, some of which have been discharged to the ground. Various constituents in the wastes have percolated to the unconfined ground water and the Columbia River. Although extensive research has been conducted under the Hanford Environmental Monitoring Program to define the distribution and concentrations of radionuclides in the ground water beneath the Hanford Site, additional information is needed to adequately determine the distribution, movement, and concentrations of hazardous chemicals.

In October 1984, an equipment evaluation study was proposed under the Hanford Ground-Water Monitoring Project, which is conducted by the Pacific Northwest Laboratory for the U.S. Department of Energy. The purpose of this study was to evaluate how well construction materials and ground-water sampling equipment affect measured concentrations of volatile organic compounds in the ground water beneath the Hanford Site.

Two monitoring wells, located at the north end of the 300 Area (Figure 1), were sampled for this study. A specially designed well, constructed of stainless steel casing and screen, was installed adjacent to an existing well. The existing well, constructed of perforated carbon steel casing, was representative of the majority of shallow wells drilled at the Hanford Site. Groundwater samples were collected from both wells using three dedicated sampling devices. Sampling was conducted for a total of 4 weeks. Each sample was analyzed for volatile organic content by gas chromatography with electron capture detection. The data were split into three data sets and statistically analyzed to ascertain differences in concentrations of contaminants resulting from well construction materials and ground-water sampling equipment. This report contains detailed information on the design and construction of the two wells, pump selection, sampling protocol, statistical analyses, and the results obtained. 


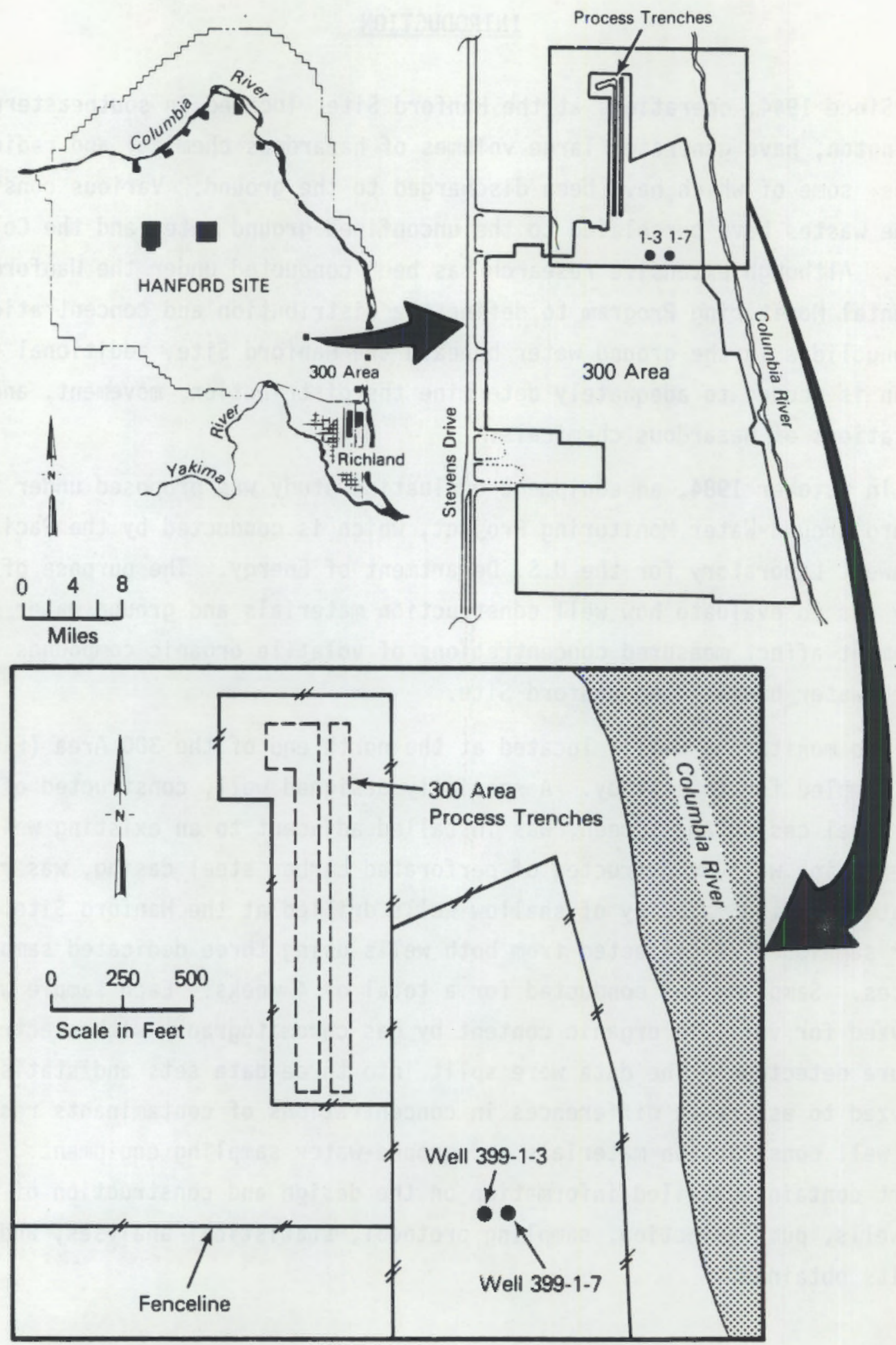

FIGURE 1. Map Showing the Location of the Study Site 


\section{CONCLUSIONS}

Results of the statistical analyses for the three data sets were generally consistent. No statisticaliy significant differences in concentrations of perchloroethylene (PCE), 1,1,1-trichloroethane (TCA), trichloroethene (TCE), and chloroform were found between samples collected in the carbon steel and stainless steel wells. No statistically significant differences in constituent concentrations were found between samples collected with the submersible pump, bladder pump, and bailer. In addition, results for a specific well type or sampling device were not consistently higher or lower for any of the constituents. However, the analyses indicate a correlation between constituent concentration and sample date and, to a lesser degree, water table elevation. These differences in concentrations were greater than the differences caused by well construction materials or ground-water sampling equipment. 



\section{METHODS}

Field operations and data collection were conducted in four phases: 1) site selection, 2) well design and construction, 3) pump selection, and 4) sample collection and analysis. Details of each phase are described below.

\section{SITE SELECTION}

The study site was selected based on two criteria: 1) the study needed to be conducted in an area of known ground-water contamination, and 2) an existing shallow well needed to be located hydraulically downgradient from the source of contamination. Two recent unplanned releases to the 300 Area Process Trenches and the location of well 399-1-3 downgradient of the trenches satisfied both criteria. In November 1982, approximately 120 gal of PCE were accidentally discharged to the process trenches. A second incident occurred in July 1984, when approximately 20 gal of PCE were discharged to the trenches. Concentrations of the contaminant were monitored in adjacent downgradient wells, including well 399-1-3, through September 1984. Low-level concentrations of PCE were thought still to be present in the ground water when this study was initiated. Figure 1 shows the locations of the process trenches, wells 399-1-3 and 399-1-7, and the Columbia River.

\section{WELL DESIGN AND CONSTRUCTION}

Well 399-1-3 was drilled using the cable tool method in April 1950. The well is located approximately $650 \mathrm{ft}$ to the southeast of the process trenches (Figure 1). Figure 2 is an as-built diagram of this well. The well was drilled to a depth of $102 \mathrm{ft}$ using 8-in.-diameter carbon steel casing. It was then perforated from 25 to $70 \mathrm{ft}$ with a Mill's-Knife(a) perforator. In October 1977 , a wooden and cement plug was set at $75 \mathrm{ft}$. Initial depth to water was $34 \mathrm{ft}$ below the top of the casing. The casing elevation is $386.70 \mathrm{ft}$ above mean sea revel (MSL).

(a) Mill's-Knife is a registered product of Barry Criswe11, Portland, Oregon. 


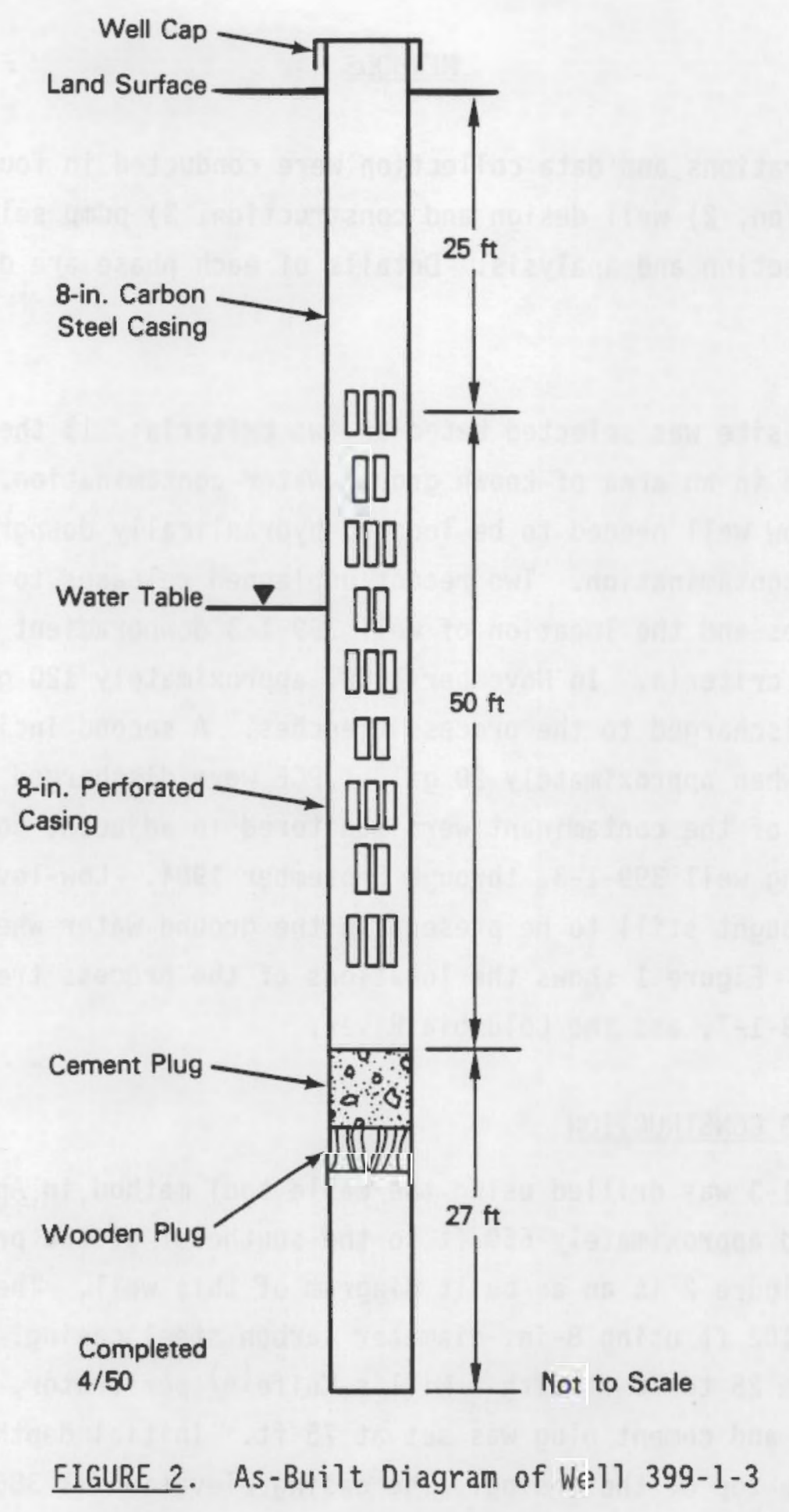


Well 399-1-7 was constructed $20 \mathrm{ft}$ to the east of well 399-1-3 (Figure 1). This well was completed in March 1985. The following precautions were taken before and during drilling operations for this well:

- The well was drilled by the cable tool method to satisfy sediment sampling needs and restrict contaminant infiltration.

- The drill rig and peripheral equipment (i.e., drill tools, cables, etc.) were cleaned with a high-pressure washer before being brought on site. No detergents were used.

- All well construction materials were similarly washed inside and outside and stored off the ground.

- The drilling contractor used only inorganic lubricants in making up tool strings.

- No drilling additives were allowed. All water used during drilling operations was obtained from the 300 Area Fire Station.

Figure 3 is an as-built diagram of well 399-1-7. The well design was based on recommendations in Test Methods for Evaluating Solid Waste; Chapter 3 Draft (USEPA 1982). We11 399-1-7 was drilled to a depth of $75 \mathrm{ft}$. As the well was drilled, samples of the materials penetrated were collected at $5-\mathrm{ft}$ intervals. A $50-\mathrm{ft}$ section of 6 -in.-diameter stainless steel screen (continuous wire wrap) was installed at the bottom of the well. Screen slot size ( 0.015 in.) was determined by a sieve analysis, with final slot size based on a $50 \%$ pass through. A stainless steel plate was welded to the bottom of the screen. The top of the screen was threaded to 6 -in. stainless steel casing, which extends approximately $2 \mathrm{ft}$ above the ground surface. The annular space was sealed with a bentonite and cement grout to a depth of $15 \mathrm{ft}$. The surface was then sealed with a concrete pad that is $3 \mathrm{ft}$ by $3 \mathrm{ft}$ and 4 in. thick. Initial depth to water was $37 \mathrm{ft}$ below the top of the casing. The casing elevation is $387.59 \mathrm{ft}$ above MSL.

Two of the three geologic formations underlying the 300 Area were either partially or fully penetrated during drilling operations for wells 399-1-3 and 399-1-7. They are, in descending order, the Hanford formation and the Ringold Formation. The Columbia River Basalts, which compose the third formation underlying the 300 Area, were not encountered in these wells. Both wells 


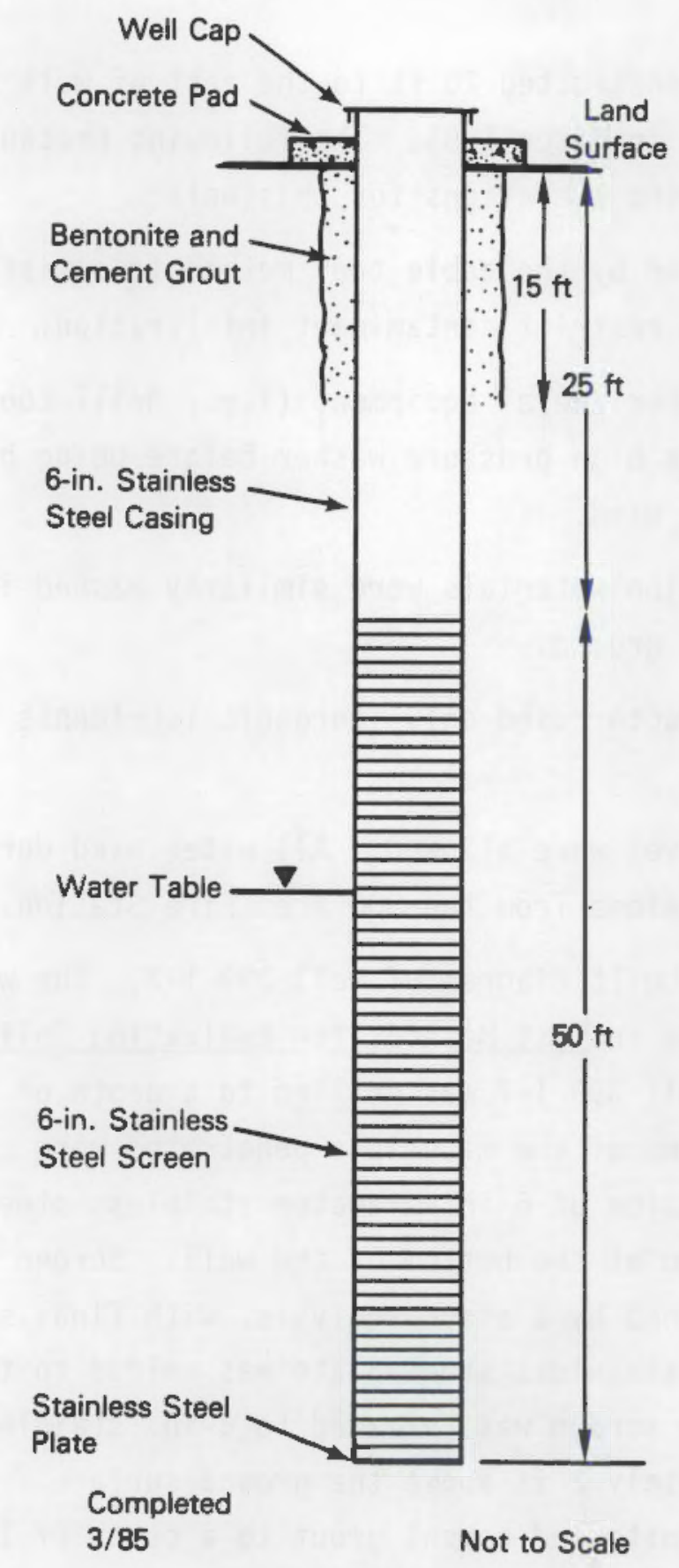

FIGURE 3. As-Built Diagram of Well 399-1-7

were completed in the upper portion of the unconfined aquifer. The water table is approximately $35 \mathrm{ft}$ below the land surface, and the saturated thickness of the unconfined aquifer in this area is approximately $65 \mathrm{ft}$. Figure 4 is a hydrogeologic log for both monitoring wells. 


\section{PUMP SELECTION}

Three dedicated sampling devices were tested in this study: the PeabodyBarnes 0.5-hp submersible pump(a); the QED Model \#T-1200 Well Wizard bladder pump(b); and the Galtek Model \#219-4 Teflon(c) bailer(d). The submersible pump was chosen because it is the standard sampling device used for the Hanford Ground-Water Monitoring Project. The bladder pump and Teflon bailer were chosen because both have been identified in the hydrologic literature (Barcelona et al. 1983) as recommended sampling devices for hazardous chemical wastes. Each device was thoroughly cleaned with water and mild soap before initial use.

\section{SAMPLE COLLECTION AND ANALYSIS}

This phase was subdivided into three parts: 1) collection methods and equipment, 2) chain of custody, and 3) analytical parameters.

\section{Collection Methods and Equipment}

Sampling procedures for this study were adapted from existing procedures used in the Hanford Ground-Water Monitoring Project. These procedures were modified to sample for volatile organic compounds as recommended in Test Methods for Evaluating Solid Waste; Chapter 3 Draft (USEPA 1982). Samples were collected in acid-cleaned, $100-\mathrm{ml}$ crimp seal vials. The crimp seals contained Teflon-lined silicone septa. Before sampling, each vial was rinsed twice with well water. Samples were collected with no head space to minimize the possibility of volatilizing the organics. After sealing, each vial was labeled, zip-locked in a plastic bag, and placed on ice for transfer to the analytical laboratory.

(a) Peabody-Barnes submersible pump is a product of Peabody-Barnes Inc., Mansfield, Ohio.

(b) Well Wizard is a registered trademark of Q.E.D. Environmental Systems, Inc., Ann Arbor, Michigan.

(c) Teflon is a registered trademark of the E.I. Du Pont de Nemours Company, Wilmington, Delaware.

(d) The Galtek bailer is a product of Galtek Corporation, Chaska, Minnesota. 


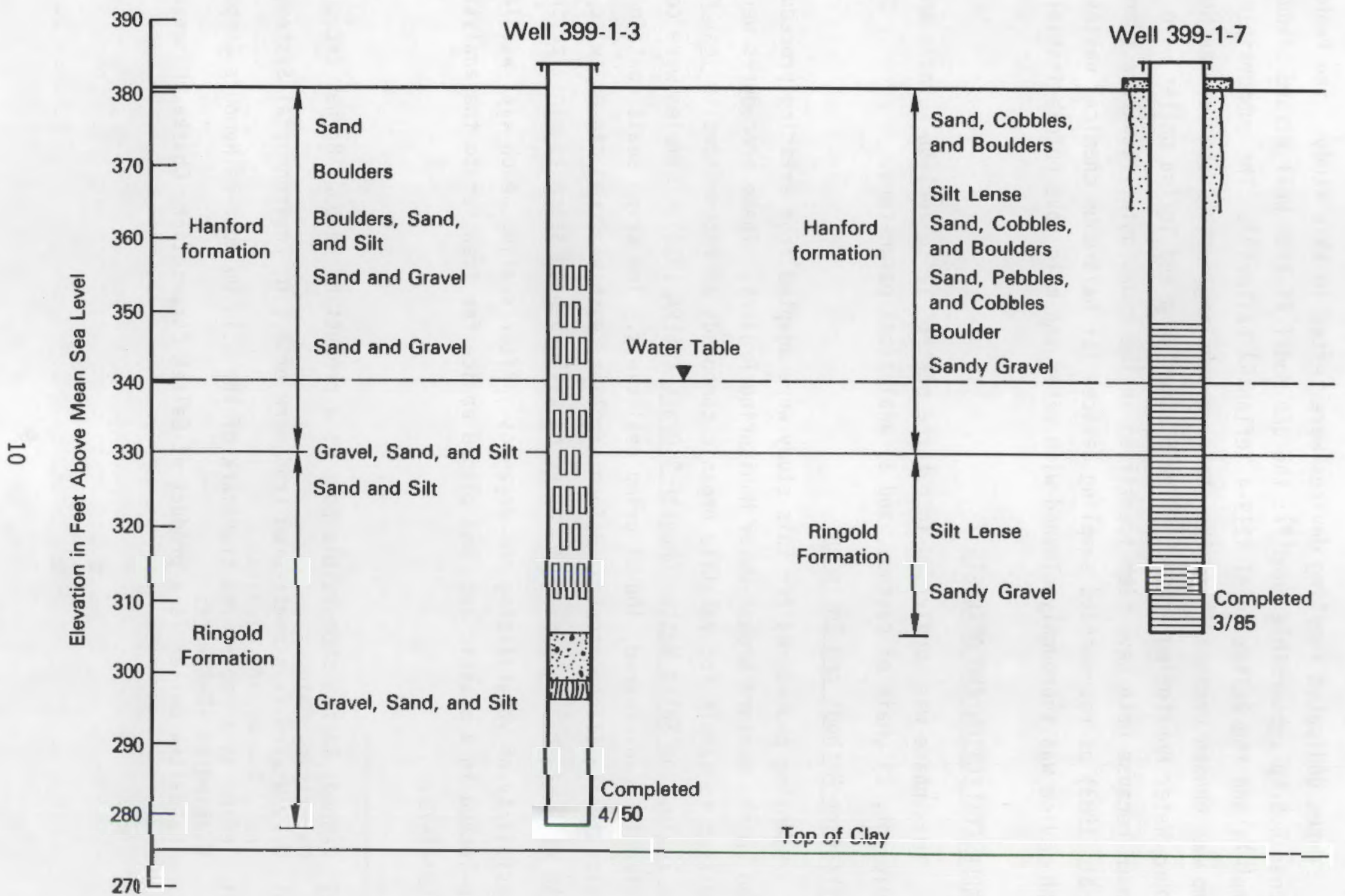

FIGURE 4. Hydrogeologic Log for Wells 399-1-3 and 399-1-7 
Sampling was conducted for 3 weeks in May 1985 and 1 week in September 1985. Samples were drawn on consecutive days each week, Tuesday and Wednesday. The specific sampling protocol for each day was as follows. The depth to water was measured in each well using a graduated steel tape. The wells were alternately sampled, beginning with well 399-1-7 on day one. The submersible pump in the first well was run for $15 \mathrm{~min}$ to purge the well. During this time, temperature, $\mathrm{pH}$, and specific conductivity were measured to ensure that the well bore was sufficiently evacuated. After these measurements stabilized, a sample was collected with the submersible pump and the pump was turned off. The bladder pump was then run for 5 min after which a sample was collected and the pump was turned off. The bailer was then lowered and rinsed two times with well water, and a sample was collected. The second well was sampled in a similar manner using the same pump order.

\section{Chain of Custody}

Chain of custody was established for the ground-water samples through the use of a field log book, environmental monitoring trip logs, laboratory record book, and computer spreadsheets. Sample number, date and time collected, $\mathrm{pH}$, conductivity, temperature, and pumping time were recorded in both the field $\log$ book and on the daily trip log. The field $\log$ book was maintained by the site geologist and the trip logs by the sample collection technicians. Each set of samples was accompanied by a trip log that was signed by the laboratory technician on receiving the samples. All of the analytical results were registered in a laboratory record book. These results were transferred to computer spreadsheets for statistical analysis.

\section{Analytical Parameters}

Ground-water samples were analyzed for PCE using gas chromatography with electron capture (GC-EC) detection as specified in EPA Method 601 (USEPA 1979). This system contains a purge and trap sampler designed to volatilize and trap volatile organics. Analyte peaks were generated on a strip chart recorder and compared to standard solutions for quantification. Analysis using GC-EC is extremely sensitive to halogenated organics, including chlorinated hydrocarbons such as PCE. The detection limit for PCE is $0.1 \mathrm{ppb}$. In addition to PCE, seven other contaminant peaks were detected in the samples. Three of these peaks were of sufficient magnitude to be considered additional data sets. 
These three constituents were identified as TCA, TCE, and chloroform. The detection limits for these constituents are $0.2,0.2$, and $0.5 \mathrm{ppb}$, respectively. The identification of these compounds was confirmed by gas chromatography mass spectrometry (GC/MS) analysis using EPA Method 624 (USEPA 1979). Results from the two analytical methods were consistent. 


\section{STATISTICAL ANALYSIS}

The analytical data are listed in chronological order in Table 1. The ground-water samples were assigned a case number and classified by collection date and time; sample number; week and day; water table elevation; well number; pump type; laboratory replicate number; concentrations of PCE, TCA, TCE, and chloroform; and comments. A total of 58 cases, representing 48 ground-water samples, were analyzed. Duplicate analyses were performed on seven samples and three blanks were submitted to evaluate laboratory precision and bias.

\section{PRELIMINARY REVIEW OF THE DATA}

The data were screened for anomalies. Based on this screening, three data sets, consisting of 39,36 , and 32 cases, were defined. Each successive data set was a subset of the previous set. The three data sets, designated Subset-1, Subset-2, and Subset-3, were analyzed individually. The rationale for dividing the data into sets is described below.

\section{Subset-1}

Subset-1 consisted of 39 cases (Table 2). A total of 19 cases were removed from the original data set to form this subset. These 19 cases were removed for several reasons. First, 12 samples drawn from well 399-1-7 with the bladder pump (cases 2, 3, 17, 18, 24, 27, 28, 34, 35, 45, 51, and 54; Table 1) had concentrations of PCE and TCA that were consistently higher throughout the study than those for all other samples from either we11. These high PCE values are shown in Figure 5 , where PCE concentrations are plotted as a function of sample date. The squares in Figure 5 represent samples collected with the bladder pump in well 399-1-7. The circles represent samples collected from all other equipment in both wells.

Investigations by the manufacturer confirmed the existence of low levels of chlorinated hydrocarbons in this bladder pump. These levels were the result of a Tefion lubricant used in the construction of the pump. The PCE and TCA concentrations in these samples remained high, despite purging water through the pump immediately before sample collection as suggested by the manufacturer. Accordingly, these 12 samples were removed from the study. 


\section{TABLE 1. Analytical Data for the Equipment Evaluation Study}

\begin{tabular}{|c|c|c|c|c|c|c|c|c|c|c|c|c|c|c|}
\hline $\begin{array}{c}\text { Case } \\
\text { Number } \\
\end{array}$ & $\begin{array}{c}\text { Collection } \\
\text { Date } \\
\end{array}$ & $\begin{array}{l}\text { Collection } \\
\text { Iime (hr) } \\
\end{array}$ & $\begin{array}{l}\text { Sample } \\
\text { Number }\end{array}$ & $\begin{array}{l}\text { Samplo } \\
\text { Meok } \\
\end{array}$ & Sapie & $\begin{array}{c}\text { Water } \\
\text { Table } \\
\text { Elevation } \\
(\mathrm{ft})(\mathrm{a}) \\
\end{array}$ & $\begin{array}{c}\text { Mell } \\
\text { Number }\end{array}$ & Pu Type & $\begin{array}{c}\text { Laboratery } \\
\text { Repli icate } \\
\text { Number } \\
\end{array}$ & $\begin{array}{c}\text { PCE } \\
\text { (Ppb) }\end{array}$ & $\begin{array}{c}\text { TCA } \\
(\text { epo })\end{array}$ & $\begin{array}{c}\text { TCE } \\
\text { (epb) }\end{array}$ & $\begin{array}{l}\text { Chioroform } \\
(\mathrm{ppb})\end{array}$ & Comments \\
\hline 1 & $5=1-85$ & 0751 & $4400-0$ & 1 & 1 & 344.69 & $i-7$ & Sutmers 1ble & i & 12.1 & 1.1 & 4.4 & 8.2 & \\
\hline 2 & $5-1-25$ & 0800 & $4400-1$ & 1 & 1 & 344.89 & $1-7$ & Bl adder & 1 & $\$ 1.6$ & 3.0 & 5.5 & 9.6 & \\
\hline 3 & $5-1-85$ & 0800 & $4400-1$ & 1 & 1 & 346.89 & 107 & Bl adder & 2 & $\$ 1.0$ & 4.2 & 4.8 & 10.4 & Splte (CC/MS) \\
\hline 4 & 5.1 .85 & 0211 & $4400-2$ & 1 & 1 & 344.89 & $1=7$ & Batler & 9 & 13.3 & 1.9 & 4.9 & 10.2 & \\
\hline 5 & $5-1-85$ & 0816 & $4400-3$ & $i$ & 1 & $M(b)$ & $m$ & ma & 1 & 0.3 & $--(e)$ & $\cdots$ & - & Transfer Blank \\
\hline 6 & $5-1-65$ & 0816 & $4400-3$ & 1 & 1 & $\mathrm{ma}$ & $m$ & NA & 2 & 0.3 & $=$ & $m$ & - & Transfer (Split) \\
\hline 7 & $5-1-85$ & 0018 & $4400-4$ & 1 & 1 & $\mathrm{Ma}$ & $m$ & $\mathrm{Ma}$ & 1 & 0.0 & $=$ & $=$ & 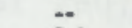 & Field Biank \\
\hline-8 & $5-1-85$ & 0838 & $4406=0$ & i & 1 & 344.90 & $1-3$ & Submersible & 1 & 10.0 & 0.8 & 3.1 & 7.8 & \\
\hline 9 & $5-1-85$ & 0038 & $4406=0$ & 1 & 1 & 344.90 & $1-3$ & Submersible & 2 & 11.0 & - & - & $-\infty$ & Spltt \\
\hline 10 & $5-1-85$ & $08 * 7$ & $4406-1$ & 1 & 1 & 344.90 & $1=3$ & Bl adder & 1 & 14.0 & 1.1 & 4.4 & 12.1 & \\
\hline 11 & $5=1-85$ & 0857 & $4406-2$ & 1 & 1 & 344.90 & $1-3$ & Batier & 1 & 13.7 & 1.6 & 4.9 & 37.7 & \\
\hline 12 & $5-1-85$ & 0859 & $4406-3$ & 1 & 1 & $\mathrm{Ma}$ & NA & Mu & 1 & 0.0 & $\because$ & 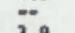 & $\ddot{0}$ & Transfer Bl ank. \\
\hline 13 & $5-2-85$ & 0802 & $406=4$ & 1 & 2 & 344.98 & $1-3$ & Subeersible & 1 & 16.0 & 1.2 & 3.9 & 9.9 & \\
\hline 14 & $5-2-85$ & 0813 & $4406-5$ & 1 & $\overline{2}$ & 344.98 & $1-3$ & Bl adder & 1 & 14.7 & 1.7 & .9 & 12.4 & \\
\hline is. & $5-2-85$ & 0.22 & $406-6$ & 1 & 2 & 344.98 & $1-3$ & Bailer & 1 & 14.9 & 1.8 & 5.4 & 37.5 & \\
\hline 16. & $5-2-85$ & 0041 & $4400-5$ & 1 & 2 & 344.95 & $1-7$ & Subeorsible & 1 & 15.9 & 1.6 & 6.6 & 14.5 & \\
\hline 17 & $5-2-85$ & 0852 & $4400-6$ & 1 & 2 & 344.95 & $1=7$ & Bladder & 1 & 50.0 & 3.3 & 6.4 & 13.2 & \\
\hline 18 & $5-2-85$ & 0852 & $4400-6$ & 1 & 2 & 344.95 & $1-7$ & Bl adder & 2 & 50.8 & $\because$ & 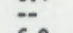 & $-\infty$ & Split \\
\hline 19 & $5-2-85$ & 0903 & $4400-7$ & 1 & 2 & 344.95 & $1-7$ & Bailer & 1 & 14.6 & 2.1 & 6.9 & 14.2 & \\
\hline 20 & $5-8-85$ & 0802 & $\leftrightarrow 06=7$ & 2 & 3 & 346.26 & $1-3$ & Subersible & 1 & 9.0 & 1.0 & 10.1 & 10.3 & No Ice \\
\hline 21 & $5=0.65$ & 0814 & $4406-8$ & 2 & 3 & 346.26 & $1-3$ & Bi addier & 1 & 0.3 & 0.2 & 0.6 & 2.1 & Broken Vial \\
\hline 22 & $5-3-85$ & 0821 & $4406-9$ & 2 & 3 & 346.26 & $1-3$ & Batler & 1 & 9.8 & 1.1 & 9.0 & 12.9 & No lee \\
\hline 23 & $5-8-65$ & 0839 & $4400-8$ & 2 & 3 & 346.24 & $1-7$ & Submersible & 1 & 9.4 & $i .1$ & 11.1 & 12.4 & No $1 \mathrm{co}$ \\
\hline 24 & $5-8-85$ & 0848 & $4000-9$ & 2 & 3 & 346.24 & $1-7$ & Bl odder & $i$ & 19.7 & 2.1 & 11.9 & 16.7 & No I eo \\
\hline 25 & $5-8-85$ & 0854 & $4400-\hat{A}$ & 2 & 3 & 346.26 & $1-7$ & Eafler & 1 & 10.2 & 1.1 & 10.4 & 11.8 & No lee \\
\hline 25 & $5-9-85$ & 0759 & $4400-8$ & 2 & 4 & 346.46 & $1-7$ & Subaersible & 1 & 11.5 & 1.3 & 13.2 & 12.5 & \\
\hline 27 & $5-9-45$ & 0809 & $4400-c$ & 2 & 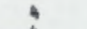 & 346.46 & $1-7$ & Bladder & 1 & 19.8 & 2.0 & 13.1 & 11.1 & \\
\hline 20 & $5-9-85$ & 0809 & $4400-c$ & 2 & 4 & 346.46 & $1-7$ & Bl adder & 2 & 18.6 & $\because$ & $\infty$ & - & Split \\
\hline 29 & $5-9-85$ & 0815 & $4400=0$ & 2 & 4 & 346.46 & $1-7$ & Batler & 1 & 13.0 & 1.4 & 15.0 & 11.5 & \\
\hline 30 & $5-9-85$ & 0833 & $4406-A$ & 2 & 4 & 346.52 & $1-3$ & Subnersible & 1 & 12.7 & 3.3 & 13.6 & 16.4 & \\
\hline 31 & $5-9-85$ & 0840 & $4406-8$ & 2 & + & 346.52 & $1-3$ & Bl adder & 1 & 12.0 & 2.0 & 13.0 & 16.9 & \\
\hline 32 & $5=9-85$ & 0849 & $4406-c$ & 2 & 4 & 346.52 & $1-3$ & Baller & 1 & 14.0 & 1.5 & 10.9 & 11.9 & \\
\hline 33 & $5-15-85$ & 0736 & $400-E$ & 3 & 5 & 346.45 & $1-7$ & Submersible & 1 & 9.2 & 1.4 & 15.0 & 10.4 & \\
\hline 34 & $5-15-85$ & 0751 & $4400-F$ & 3 & 5 & 346.45 & $1-7$ & Bl adder & 1 & 16.3 & 2.1 & 16.0 & 11.8 & \\
\hline 35 & $5-15-85$ & 0751 & $4400-F$ & 3 & 5 & 346.45 & $i-7$ & Bladder & 2 & 17.2 & $=$ & 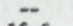 & $\cdots$ & Split \\
\hline 36 & $5-15-85$ & 0759 & $4400-C$ & 3 & 5 & 346.45 & $1=7$ & Bailer & 1 & 10.3 & 1.9 & 16.6 & 11.5 & \\
\hline 37 & $5-15-85$ & 0818 & $4406-D$ & 3 & 5 & 346.48 & $1-3$ & Subnersible & 1 & 9.2 & 1.5 & 15.8 & 10.9 & \\
\hline 30 & $5-15-85$ & 0829 & $4406-E$ & 3 & 5 & 346.48 & $1-3$ & Bl adder & $?$ & 9.1 & 2.0 & 15.2 & 10.1 & \\
\hline 39 & $S-15-85$ & 0839 & $4406-F$ & 3 & 5 & 346.48 & $1-3$ & Batler & 1 & 9.0 & 1.4 & 12.9 & 9.3 & \\
\hline 40 & $5-16-85$ & 0737 & $4406-C$ & 3 & 6 & 346.73 & $1-3$ & Sutmersible & 1 & 11.0 & 1.2 & 17.6 & 10.2 & CC/NS \\
\hline 41 & $5-16-85$ & 0745 & $4406-+1$ & 3 & 6 & 346.73 & $i=3$ & Bl adder & 1 & 9.7 & 1.5 & 14.1 & 9.9 & \\
\hline 42 & $5-16-85$ & 0752 & $4406-1$ & 3 & 6 & 346.73 & $1-3$ & Batler & 1 & 10.1 & 1.5 & 14.8 & 10.6 & \\
\hline 43 & $5-16-85$ & 0810 & $4400-k$ & 3 & 6 & 346.77 & $1-7$ & Submersfble & 1 & 9.9 & 1.4 & 14.9 & 9.8 & \\
\hline 44 & $3-16-85$ & 0810 & $4400-\mathrm{H}$ & 3 & 6 & 346.77 & $1-7$ & Subeersible & 2 & 9.8 & $\because$ & $\therefore$ & $\because$ & split \\
\hline 45 & $5-16-85$ & 0820 & $\$ \$ 00-1$ & 3 & 5 & 346.77 & $3-7$ & Bladder & 1 & 14.5 & 2.6 & 14.9 & 10.3 & \\
\hline 46 & $5-16-85$ & 0827 & $4400-J$ & 3 & 6 & 346.77 & $1=7$ & Bailer & 1 & 9.6 & 1.2 & 16.7 & 10.9 & CCMAS \\
\hline 47 & $9-10-85$ & 0734 & $4406-J$ & 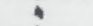 & 7 & 342.37 & $1-3$ & Submera ible & 1 & 12.4 & 0.1 & 3.3 & 24.0 & \\
\hline 48 & $9-10-85$ & 0743 & $4406-x$ & 4 & 7 & 342.37 & $1-3$ & Bl adder & $!$ & 10.2 & 0.1 & 3.7 & 21.5 & \\
\hline 49 & $9-10-05$ & 0753 & 4406-L & 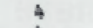 & 7 & 342.37 & $1-3$ & Batler & 1 & 14.9 & 0.1 & 4.2 & 27.4 & \\
\hline so & $9-10-85$ & 0811 & $4400=K$ & 4 & 7 & 342.37 & $1-7$ & Subnersible & 1 & 11.2 & 0.1 & 3.2 & 23.2 & \\
\hline 51 & $9-10-85$ & 0823 & $4400-L$ & + & 7 & 342.37 & $i-7$ & Bl adder & 1 & 72.1 & 3.0 & 2.7 & 24.2 & \\
\hline 52 & $9-10-85$ & 0830 & $4400-M$ & 4 & 7 & 342.37 & $1-7$ & Bailer & 1 & 13.0 & 0.0 & 3.2 & 26.0 & \\
\hline 53 & $9-11-85$ & 0734 & $4400-K$ & 4 & 8 & 342.28 & $1-7$ & Submersible & 3 & 11.7 & 0.2 & 3.3 & 24.7 & \\
\hline 54 & $9-11-85$ & 0745 & $4400=0$ & i & 8 & 342.26 & $1-7$ & Bl adder & $i$ & 38.8 & 2.8 & 2.0 & 24.9 & - \\
\hline 55 & $9-11-85$ & 0751 & $4400-p$ & + & 8 & 342.28 & $1-7$ & Bailer & $i$ & 12.9 & 0.1 & 2.2 & 25.2 & \\
\hline 56 & $9-11-85$ & 0810 & $4406-M$ & $\omega$ & $\theta$ & 342.28 & $1-3$ & Submersible & $?$ & 6.8 & 0.1 & 1.6 & 13.2 & \\
\hline 57 & $9-11-85$ & . 0820 & $4406 \cdot \mathrm{N}$ & 4 & 6 & 342.28 & $1-3$ & Bladder & 1 & 8.6 & 0.0 & 2.4 & 19.2 & \\
\hline se & $9-11-85$ & 0825 & $\$ 406-0$ & 4 & 8 & 342.28 & $1-3$ & Batlor & 1 & 0.3 & 0.1 & 1.9 & 15.9 & \\
\hline
\end{tabular}

Two samples drawn from well 399-1-3 with the bailer (cases 11 and 15; Table 1) had chloroform concentrations that were 23 to $30 \mathrm{ppb}$ higher than al1 other chloroform concentrations analyzed on those 2 days (cases $1,4,8$ to $10,13,14,16$, and 19; Table 1). The maximum variation in chloroform concentrations on one sample day for the remaining six sample days was $6.0 \mathrm{ppb}$. These differences were not observed in the concentrations of the other three constituents, therefore, cases 11 and 15 were removed from the study. 
TABLE 2. Analytical Data in Subset-1

\begin{tabular}{|c|c|c|c|c|c|c|c|c|c|c|c|c|c|c|}
\hline $\begin{array}{l}\text { Cuse } \\
\text { Number }\end{array}$ & $\begin{array}{c}\text { Collection } \\
\text { Date } \\
\end{array}$ & $\begin{array}{l}\text { Collection } \\
\text { Time (hr) }\end{array}$ & $\begin{array}{l}\text { Somple } \\
\text { Number }\end{array}$ & $\begin{array}{l}\text { Sample } \\
\text { Weak }\end{array}$ & Semplo & $\begin{array}{c}\text { Water } \\
\text { Tobil } \\
\text { Elovation } \\
\text { (ft)(a) }\end{array}$ & $\begin{array}{c}\text { Well } \\
\text { number }\end{array}$ & Pule Type & $\begin{array}{l}\text { Laborstory } \\
\text { Repllfeote } \\
\text { Number } \\
\end{array}$ & $\begin{array}{c}\text { PCE } \\
\text { (ppo) }\end{array}$ & $\begin{array}{c}\text { TCa } \\
\text { (pob) }\end{array}$ & $\begin{array}{c}\text { TCE } \\
\text { (ppb) }\end{array}$ & $\begin{array}{c}\text { Chioroform } \\
\text { (ppb) }\end{array}$ & Comments \\
\hline 1 & $5-1-85$ & 0751 & $4400=0$ & 1 & 1 & 344.89 & 1.7 & Submersible & 1 & 12.1 & 1.1 & 4.4 & 8.2 & \\
\hline 4 & $5-1-85$ & 0811 & $4400-2$ & i & i & 344.89 & $i-7$ & Bailer & $i$ & 13.3 & 1.1 & 4.9 & 10.2 & \\
\hline a & $5-1-85$ & $\infty 838$ & $4406-0$ & 1 & ; & 344.90 & $1-3$ & Submersible & 1 & 10.0 & 0.8 & 3.1 & 7.0 & \\
\hline 9 & $5-1-85$ & 0838 & $4406=0$ & $i$ & $i$ & 344.90 & $i-3$ & Sulmarsible & 2 & 11.0 & $-(b)$ & $-\infty$ & -- & Split \\
\hline 10 & $5-1-85$ & 0847 & $4406-1$ & $i$ & i & 344.90 & $1-3$ & Bl adder & 1 & 14.0 & $1.1^{-1}$ & 4.4 & 12.1 & \\
\hline 13 & $5-2-85$ & 0802 & $4406-4$ & i & 2 & 344.98 & $1-3$ & Submersible & 1 & 14.0 & 1.2 & 3.9 & 9.9 & \\
\hline 14 & $5-2-85$ & 0813 & $4406-5$ & i & $\overline{2}$ & 344.98 & $1-3$ & Blodder & 1 & 14.7 & 1.7 & 4.5 & 12,4 & \\
\hline 16 & $5-2=85$ & oghi & $4400-5$ & $i$ & 2 & 344.95 & $1-7$ & Submersible & 1 & 15.9 & 1.6 & 6.6 & 14.5 & \\
\hline 19 & $5-2-85$ & 0903 & $4400-7$ & 1 & $i$ & 344.95 & $1-7$ & Bailer & $i$ & 14.6 & 2.1 & 6.9 & 14.2 & \\
\hline 20 & $5=8-85$ & 0802 & $4406-7$ & 2 & 3 & 346.26 & $1-3$ & Subnersibl• & 1 & 9.8 & 9.0 & 10.1 & 10.3 & Mo lee \\
\hline 22 & $s=0-8 s$ & 0821 & $4406-9$ & 2 & 3 & 346.26 & $i-3$ & Basiler & $i$ & 9.8 & 1.1 & 9.0 & 12.9 & No ice \\
\hline 23 & $5-8-85$ & 0039 & $4400-8$ & 2 & 3 & 346.24 & $1-7$ & Submersibl. & $i$ & 9.4 & 1.1 & 11.1 & 12.4 & No ice \\
\hline 25 & $5-8-85$ & 0054 & $4400-A$ & 2 & 3 & 346.24 & $1=7$ & Bafler & $i$ & 10.2 & 1.1 & 10.4 & 11.0 & No I ee \\
\hline 26 & $5=9-85$ & 0759 & $4400-8$ & 2 & 4 & 346.46 & $1-7$ & Submersible & $i$ & 11.5 & 1.3 & 13.2 & 12.5 & \\
\hline 29 & $5=9-85$ & 0815 & $4400-0$ & 2 & 4 & 346.46 & $1-7$ & Bailor & 1 & 13.0 & 1.4 & 15.0 & 11.5 & \\
\hline 30 & $5-9-85$ & 0833 & $4406-A$ & $\bar{z}$ & + & 346.52 & $j=3$ & Submersible & $i$ & 12.7 & 3.3 & 13.6 & 16.4 & \\
\hline 31 & $5=9-85$ & 0840 & $4406-8$ & 2 & 4 & 346.52 & $1-3$ & Bladder & 1 & 12.6 & 2.0 & 13.8 & 16.9 & \\
\hline 32 & $5-9-85$ & 0849 & $4406-c$ & 2 & $\$$ & 346.52 & $1-3$ & Bailer & 1 & 14.0 & 1.5 & 10.9 & 11.9 & \\
\hline 33 & $5-15-85$ & 0736 & $4400-E$ & 3 & 5 & 346.45 & $1-7$ & Submersible & $i$ & 9.2 & 1.4 & 15.0 & 10.4 & \\
\hline 36 & $5-15-85$ & 0759 & $4400-\bar{c}$ & 3 & 5 & 346.45 & $1-7$ & Bailer & $i$ & 10.3 & 1.9 & 16.6 & 11.5 & \\
\hline 37 & $5=15=85$ & 0010 & $4406=0$ & 3 & 5 & 346.40 & $i-3$ & Subaers ible & $i$ & 9.2 & 1.5 & 15.8 & 10.9 & \\
\hline 30 & $5-15-85$ & 0829 & $4406-E$ & 3 & 5 & 346.48 & $i-3$ & Bl adder & $i$ & 9.1 & 2.0 & 15.2 & 10.1 & \\
\hline 39 & $5-15-85$ & 0839 & $4406-F$ & 3 & 5 & 346.46 & $i-3$ & Boiler & $i$ & 9.0 & 1.4 & 12.9 & 9.3 & \\
\hline 40 & $5-16-85$ & 0737 & $4406-C$ & 3 & 6 & 346.73 & $1-3$ & Subnarsible & 1 & 11.0 & 1.2 & 17.6 & 10.2 & CC/MS \\
\hline 11 & $5-16-85$ & 0745 & $4406-\mathrm{H}$ & 3 & 6 & 346.73 & $1-3$ & Bladder & 1 & 9.7 & 1.5 & 14.1 & 9.9 & \\
\hline 42 & $5-16-85$ & 0732 & $4406-1$ & 3 & 6 & 346.73 & $1-3$ & Beiler & $i$ & 10.1 & 1.5 & 14.8 & 10.6 & \\
\hline 43 & $5-16-85$ & 0810 & $4400-H$ & 3 & 6 & 346.77 & $1-7$ & Submer sible & 1 & 9.9 & 1.4 & 14.9 & 9.8 & \\
\hline 44 & $5-16-85$ & 0870 & $+400-\mathrm{H}$ & 3 & 6 & 346.77 & $1-7$ & Submersible & 2 & 9.0 & - & - & - & Split \\
\hline 46 & $5-16-85$ & 0827 & $\$ 00-j$ & 3 & 6 & 366.77 & $i-7$ & Bailer & 1 & 9.6 & 1.2 & 16.7 & 10.9 & CCNMS \\
\hline 47 & $9-10-65$ & 0734 & $4406-J$ & 4 & 7 & 342.37 & $i-3$ & Submersible & $i$ & 12.4 & 0.1 & 3.3 & 24.0 & \\
\hline 48 & $9=10-65$ & 0743 & $4406-k$ & 4 & 7 & 342.37 & 1.3 & Bladder & $i$ & 10.2 & 0.1 & 3.7 & 21.5 & \\
\hline 49 & $9-10-85$ & 0753 & $4406-i$ & + & 7 & $3+2.37$ & $1-3$ & Bailer & $i$ & 14.9 & 0.1 & 4.2 & 27.4 & \\
\hline so & $9-10-85$ & 0811 & $4400-k$ & 4 & 7 & 342.37 & $1-7$ & Submersible & 1 & 11.2 & 0.1 & 3.2 & 23.2 & \\
\hline 52 & $9-10-85$ & 0830 & $400-M$ & 4 & 7 & 342.37 & $1-7$ & Bailor & $t$ & 13.0 & 0.0 & 3.2 & 26.0 & \\
\hline 53 & $9-11-85$ & 0734 & $4400-\mathrm{N}$ & 4 & . & $3 \$ 2.20$ & $1=7$ & Submersible & 1 & 11.7 & 0.2 & 3.3 & 24.7 & \\
\hline 55 & $9-11-65$ & 0751 & $4400-p$ & 4 & 0 & 342.28 & $1-7$ & Bailer & 1 & 12.9 & 0.1 & 2.2 & 25.2 & \\
\hline 56 & $9-11-85$ & 0810 & $4406-4$ & 4 & 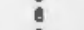 & 342.28 & $1-3$ & Submorsible & $i$ & 6.0 & 0.1 & 1.6 & 13.2 & \\
\hline 57 & $9-11-85$ & 0820 & $4406-N$ & 4 & 6 & 342.20 & $1-3$. & Bl adder & 1 & A. 6 & 0.0 & 2.4 & 19.2 & \\
\hline 58 & $9-11-85$ & 0825 & $4406=0$ & 4 & 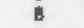 & 342.20 & $1-3$ & Bailer & 1 & 0.3 & 0.1 & 1.9 & 15.9 & \\
\hline
\end{tabular}

(a) Water table elewations are in ft above KLL. The casing olevation for woll 399-1-3 is 386.70 ft above MSL. Water table 4 levations (b) for mint cates data not provided by analytical laboratory.

Another case was removed from the study because a sample vial was broken during transport to the laboratory (case 21; Table 1). Contaminant concentrations for this sample were five to 30 times lower than concentrations for other samples collected on the same day (cases 20 and 22 to 25; Tabie 1). Therefore, case 21 was removed from the study.

The last four of the 19 cases were removed because three were transfer blank samples (cases 5, 6, and 12; Table 1), and one was a field blank sample (case 7; Table 1). These were used to evaluate laboratory precision and bias.

\section{Subset-2}

Subset-2 consisted of 36 cases (Table 3 ). A total of 3 cases were removed from Subset-1 to form this subset because concentrations for three samples drawn from we11 399-1-3 on September 11, 1985 (cases 56 to 58; Table 1) were 30 to 50\% lower than the concentrations in well 399-1-7 (cases 53 and 55; Table 1). Differences of this magnitude were not seen between wells or between 


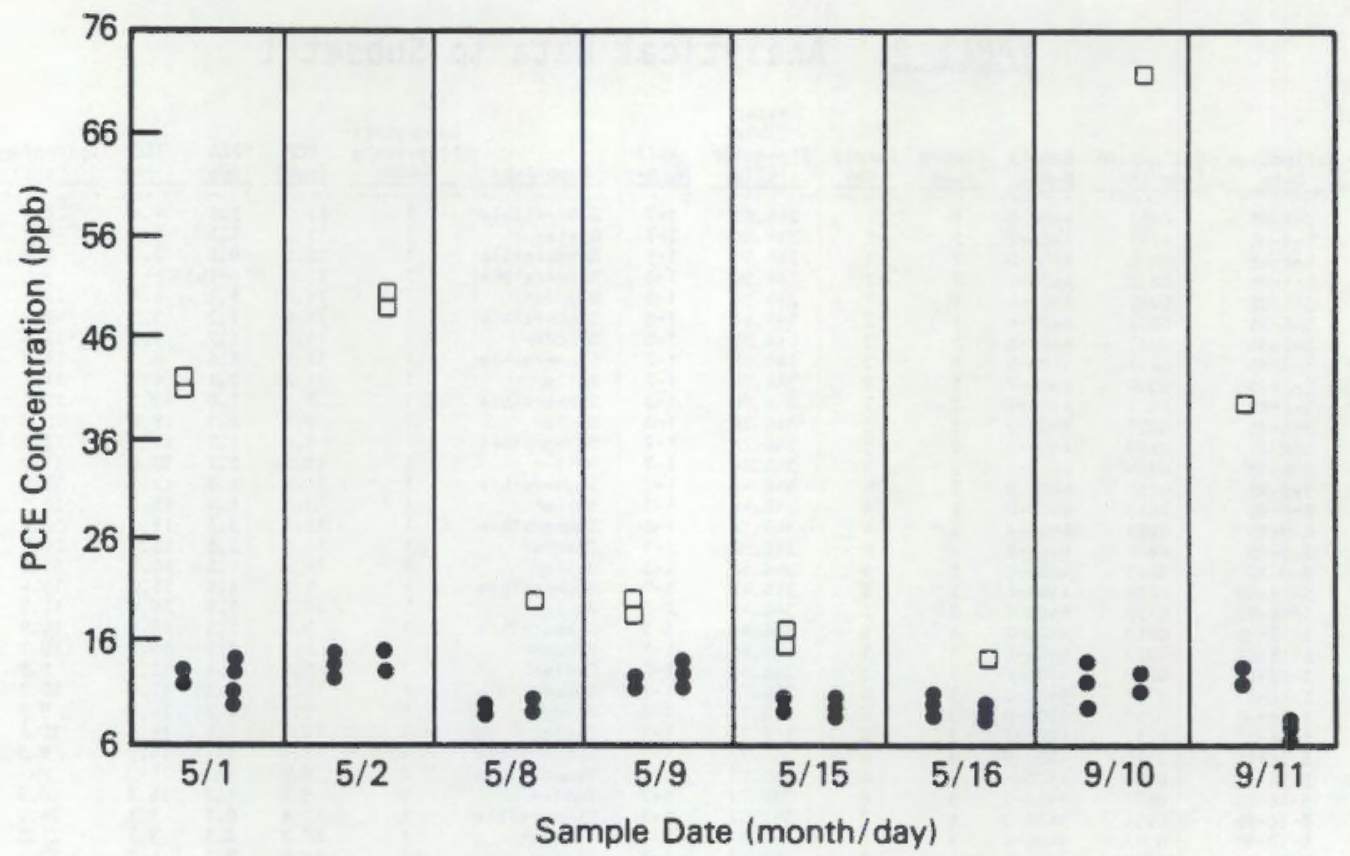

- Samples Collected with the Bladder Pump in Well 399-1-7

- Samples Collected with All Other Equipment in Both Wells

FIGURE 5. Comparison of PCE Concentrations in Samples Collected With the Bladder Pump in We11 399-1-7 and A11 Other Equipment in Both Wells

TABLE 3. Analytical Data in Subset-2

\begin{tabular}{|c|c|c|c|c|c|c|c|c|c|c|c|c|c|c|}
\hline $\begin{array}{c}\text { Case } \\
\text { Number }\end{array}$ & $\begin{array}{c}\text { Collection } \\
\text { Date } \\
\end{array}$ & $\begin{array}{l}\text { Coll loction } \\
\text { Iime (hr) } \\
\end{array}$ & $\begin{array}{l}\text { Sample } \\
\text { Number } \\
\end{array}$ & $\begin{array}{l}\text { Samplo } \\
\text { Week } \\
\end{array}$ & $\begin{array}{c}\text { Samplo } \\
\text { Day } \\
\end{array}$ & $\begin{array}{l}\text { Water } \\
\text { Table } \\
\text { Elevation } \\
(\mathrm{ft})(\mathrm{a}) \\
\end{array}$ & $\begin{array}{c}\text { Nell } \\
\text { Number }\end{array}$ & Pune type & $\begin{array}{c}\text { Laboratory } \\
\text { Replicate } \\
\text { Number } \\
\end{array}$ & $\begin{array}{c}\text { PCE } \\
\text { (PPD) }\end{array}$ & $\begin{array}{c}\text { TCA } \\
\text { (ppo) }\end{array}$ & $\begin{array}{c}\text { TCE } \\
\text { (ppob) }\end{array}$ & $\begin{array}{c}\text { Chloroform } \\
\begin{array}{c}(\mathrm{ppp}) \\
\end{array}\end{array}$ & Coments \\
\hline 1 & $5-1-85$ & 0751 & $4400-0$ & 1 & 1 & 344.89 & $1-7$ & Submersible & 1 & 12.1 & 1.1 & 4.4 & 8.2 & \\
\hline 4 & $5-1-85$ & 0811 & $4400-2$ & i & i & 344.89 & $1-?$ & Bailor & 1 & 13.3 & 1.1 & 4.9 & 10.2 & \\
\hline 8 & $5-1-85$ & 0038 & $4406-0$ & $i$ & 1 & 344.90 & $1-3$ & Submersible & 1 & 10.0 & 0.0 & 3.1 & 7.8 & \\
\hline 9 & $5-1-85$ & 0838 & $4406=0$ & 1 & $i$ & 344.90 & $1-3$ & Submersible & 2 & 11.0 & $-(b)$ & $\cdots$ & $\because$ & Splft \\
\hline 10 & $5-1-85$ & 0847 & $4406-1$ & 1 & 1 & 344.90 & $1-3$ & Bl adder & 1 & 14.0 & 1.1 & 4.4 & 12.1 & \\
\hline 13 & $5-2-85$ & 0002 & $4406-4$ & 1 & 2 & 344.98 & $1-3$ & Submersible & ! & 14.0 & 1.2 & 3.9 & 9.9 & \\
\hline 14 & $5-2-85$ & 0813 & 4406-5 & 1 & 2 & 344.98 & $1-3$ & Bl adder & i & 14.7 & 1.7 & 4.9 & 12.4 & \\
\hline 16 & $-5-2-85$ & 0841 & $400-5$ & 1 & 2 & 344.95 & $1-7$ & Subeersible & 1 & 15.9 & 1.6 & 6.6 & 14.5 & \\
\hline 19 & $5-2-85$ & 0903 & $4400-7$ & 1 & 2 & 344.95 & $1-7$ & Bailer & 1 & 14.6 & 2.1 & 6.9 & 14.2 & \\
\hline 20 & $5-8-85$ & 0802 & $4406-7$ & 2 & 3 & 346.26 & $1-3$ & Subnersible & $i$ & 9.8 & 1.0 & 10.1 & 10.3 & No Ice \\
\hline 22 & $5-8-25$ & 0821 & $4406-9$ & 2 & 3 & 346.26 & $1-3$ & Bafler & i & 9.8 & 1.1 & 9.0 & 12.9 & No lae \\
\hline 23 & $5-6-85$ & 0839 & $4400-8$ & 2 & 3 & 346.24 & $1-7$ & Subeorsibie & 1 & 9.4 & 1.1 & 11.1 & 12.4 & No lee \\
\hline 25 & $5-8-85$ & 0054 & $4400-A$ & $i$ & ja & 346.24 & 1.7 & Bailar & 1 & 10.2 & 1.1 & 10.4 & 11.8 & No ICe \\
\hline 26 & $5-9-85$ & 0759 & $4400-8$ & 2 & 4 & 346.46 & $i-7$ & Sub-ratible & 1 & 11.5 & 1.3 & 13.2 & 12.5 & \\
\hline 29 & $: 5-9-85$ & 0815 & $4400-0$ & 2 & 4 & 346.46 & $1-7$ & Bailer & 1 & 13.0 & 1.4 & 15.0 & 11.5 & \\
\hline 30 & $5-9-85$ & 0033 & $4406-A$ & 2 & 4 & 346.52 & $1-3$ & Submersible & 1 & 12.7 & 3.3 & 13.6 & 16.4 & \\
\hline 31 & $5-9-85$ & 0840 & $4406-8$ & 2 & 4 & 346.52 & $1 \cdot 3$ & Bl adder & 1 & 12.8 & 2.0 & 13.8 & 16.9 & \\
\hline 32 & $5-9-85$ & 0849 & $4406-C$ & 2 & 4 & 346.52 & $1-3$ & Bailer & 1 & 14.0 & 1.5 & 10.9 & 11.9 & \\
\hline 33 & $5=15-85$ & 0736 & $4400-E$ & 3 & 5 & 346.45 & $1=7$ & Submersibl• & 1 & 9.2 & 1.4 & 15.0 & 10.4 & \\
\hline 36 & $5-15-85$ & 0759 & $4400-\bar{C}$ & 3 & 5 & 346.45 & $1-7$ & Bailer & 1 & 10.3 & 1.9 & 16.6 & 11.5 & \\
\hline 37 & $5-15-85$ & 0818 & $4406=0$ & 3 & 5 & 346.48 & $1-3$ & Submersible & 1 & 9.2 & 1.5 & 15.8 & 10.9 & \\
\hline 38 & $5-15-85$ & 0829 & $4406-E$ & 3 & 5 & 346.40 & $1-3$ & 81 adder & 1 & 9.1 & 2.0 & 15.2 & 10.1 & \\
\hline 35 & $5-15-85$ & 0839 & $4406-7$ & 3 & s & $3+6.48$ & $1-3$ & Bailer & 1 & 9.0 & 1.4 & 12.9 & 9.3 & \\
\hline 40 & $5-16-85$ & 0737 & $4406-C$ & 3 & 6 & 346.73 & $1-3$ & Submersible & $i$ & 11.0 & 1.2 & 17.6 & 10.2 & CC/MS \\
\hline 41 & $5-16-85$ & 0745 & $406-H$ & 3 & 6 & 346.73 & $1=3$ & Bl adder & 1 & 9.7 & 1.5 & 14.1 & 9.9 & \\
\hline 42 & $5-16-85$ & 0752 & $4406-1$ & 3 & 6 & 346.73 & $1-3$ & Bailer & 1 & 10.1 & 1.5 & 14.8 & 10.6 & \\
\hline 43 & $5-16-85$ & 0810 & $4400-+1$ & 3 & 6 & 346.77 & $1-7$ & Subegrsible & 1 & 9.9 & 1.4 & 14.9 & 9.8 & \\
\hline 46 & $5-16-85$ & 0810 & $4400-+1$ & 3 & 6 & 346.77 & $1-7$ & Submersible & 3 & 9.0 & $\cdots$ & $\because$ & $=$ & Split \\
\hline 46 & $5-16-85$ & 0827 & $4400-J$ & 3 & 6 & 346.77 & $1-7$ & Bailer & 1 & 9.6 & 1.2 & 16.7 & 10.9 & $\operatorname{cc} / \mathrm{Ns}$ \\
\hline 47 & $9-10-85$ & 0734 & $4406-J$ & 4 & 7 & 342.37 & $1-3$ & Sutbersible & 1 & 12.4 & 0.1 & 3.3 & 24.0 & \\
\hline 48 & $9-10-85$ & 0743 & $4406-K$ & + & 7 & 342.37 & $1-3$ & Bladder & 1 & 10.2 & 0.1 & 3.7 & 21.5 & \\
\hline 49 & $9-10-85$ & 0753 & $4406-L$ & 4 & 7 & 342.37 & $1-3$ & Bailer & 1 & 14.9 & 0.1 & 4.2 & 27.4 & \\
\hline so & $9-10-85$ & 0811 & $4400-k$ & 4 & 7 & 342.37 & $1-7$ & Submersible & 1 & 19.2 & 0.1 & 3.2 & 23.2 & \\
\hline 52 & $9-10-85$ & 0830 & $4400-M$ & 4 & 7 & 342.37 & $1-7$ & Bafler & 1 & 13.0 & 0.8 & 3.2 & 26.0 & \\
\hline 53 & $9-11-85$ & 0734 & $4400-N$ & 4 & : & 342.38 & $1-7$ & Submersible & 1 & 11.7 & 0.2 & 3.3 & 24.7 & \\
\hline & & 0751 & $4400-P$ & 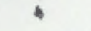 & 8 & 342.38 & $1-7$ & Bailer & 1 & 12.9 & 0.1 & 2.2 & 25.2 & \\
\hline
\end{tabular}

(a) Water table elevations ore in ft above $\mathrm{kSL}$. The casing ol evation for mil $399-1-3$ is $386.70 \mathrm{ft}$ above $\mathrm{kSL}$. Water table elevatfons

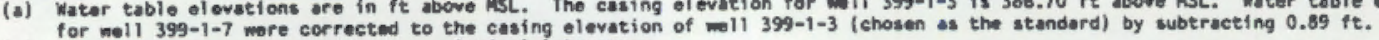

(b) for mell $399-1-7$ more corrected to the casing elevation of 
TABLE 4. Analytical Data in Subset-3

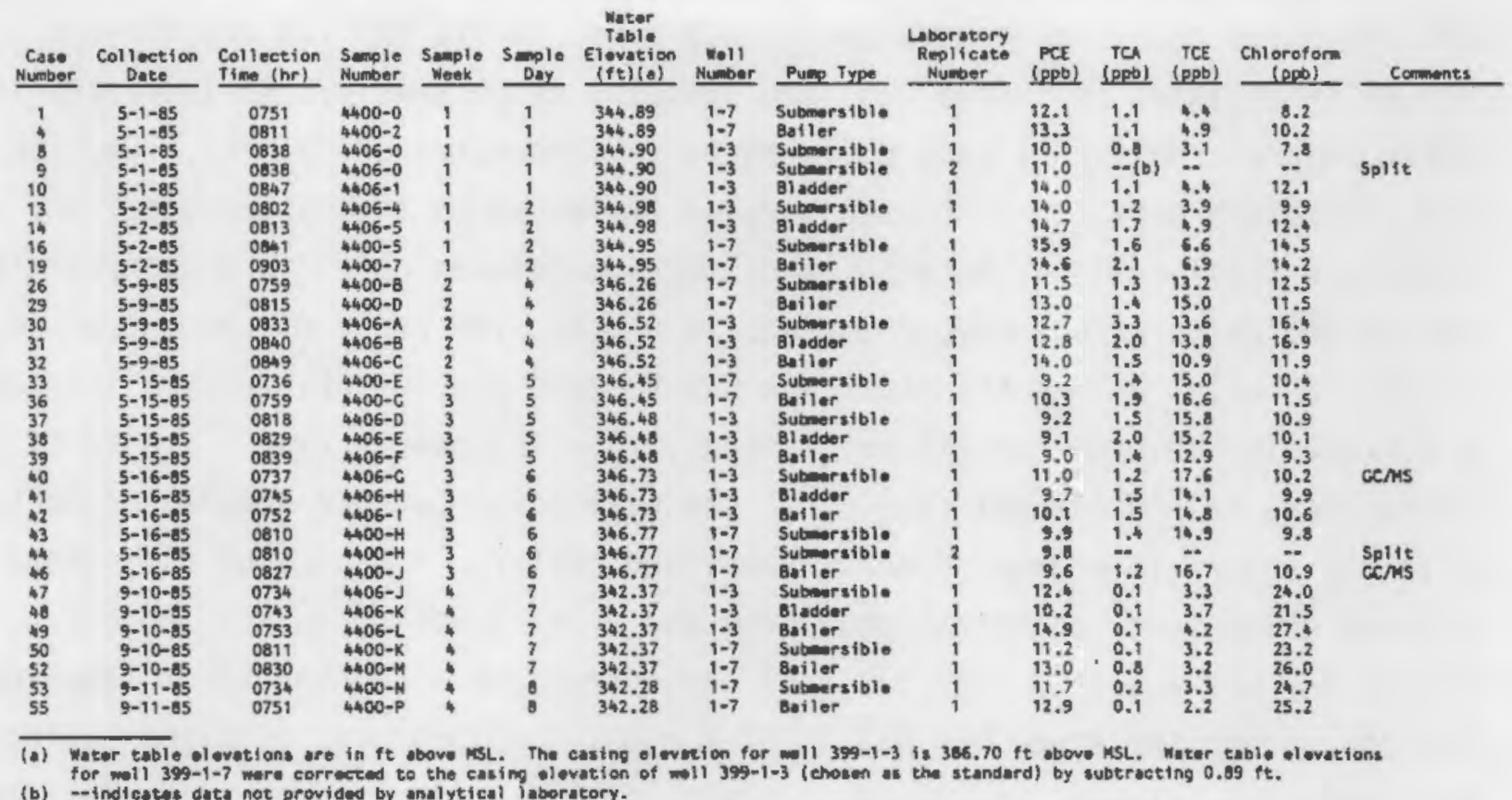

contiguous sample days during the May sampling period. These data also deviated from the results of the previous day (cases 47 to 50 ; Table 1 ).

Subset-3

Subset-3 consisted of 32 cases (Table 4). A total of 4 cases were removed from Subset-2 to form this subset. In the second week of sampling, six samples (cases 20 to 25; Table 1) were collected and stored for approximately $2 \mathrm{hr}$ without ice before arriving at the laboratory. Concentrations of these samples were lower than those of samples drawn the same week (cases 26, 29 to 32; Table 1) and the previous week (cases 1, 4, 8 to 11, 13 to 16, 19; Table 1). Cases 21 and 24 were removed previously (Table 2). Cases 20, 22, 23, and 25 were assumed to be biased low and were also removed from the study.

\section{DATA ANALYSIS}

The data were analyzed using plots of constituent concentration over time, analyses of variance and covariance, and a multivariate graph matrix with Pearson correlation coefficients. The following discussion is based on Subset-1, unless otherwise noted. 
The data are plotted in Figures $6,7,8$, and 9. Constituent concentrations are shown for each sample date, we11, and pump. Wells 399-1-3 and 399-1-7 are differentiated by shaded and open symbols, respectively. As indicated in these figures, no significant differences in concentrations of PCE, TCA, TCE, and chloroform were found between samples collected in the carbon steel and stainless steel wells. The maximum difference between chloroform concentrations in the two wells on one sample day was $12.0 \mathrm{ppb}$. The range of concentrations in the two wells during the study was 8.2 to $27.4 \mathrm{ppb}$ for chloroform, indicating a correlation between constituent concentration and sample date. No significant differences in constituent concentrations were found between samples collected with the submersible pump, bladder pump, and bailer. The maximum difference between chloroform concentrations among the three sampling devices on one sample day was $6.0 \mathrm{ppb}$. The range of concentrations among the three sampling devices during the study was 8.2 to $27.4 \mathrm{ppb}$ for chloroform, also indicating a correlation between constituent concentration and sample date. In addition, results for a specific well type or sampling device were not consistently higher or lower for any of the constituents.

Analyses of variance and covariance were used to account for the total variation from mean concentrations and attribute them to differences in wells and sampling devices. The three data sets were analyzed as $8 \times 2 \times 3$ (sample date $x$ we11 $x$ pump) factorial experimental designs (Kempthorne 1979). Water table elevation was treated as a covariate and sample date as a blocking factor to remove their influences from the differences in concentrations before testing for well or pump effects.

For each contaminant, concentration was modeled as a linear function of well type, pump type, we11/pump combination, sample date, and water table elevation. The contribution of each term in this linear model to the variation in the observed concentration was then evaluated using analyses of variance. The analyses are summarized in Table 5. Table entries (P-values) indicate whether the corresponding source of variation affected the chemical concentrations. P-values of less than 0.05 indicate significant statistical differences attributable to the source of variation. The P-values indicate that well type, pump type, and well/pump combination did not affect mean concentrations 


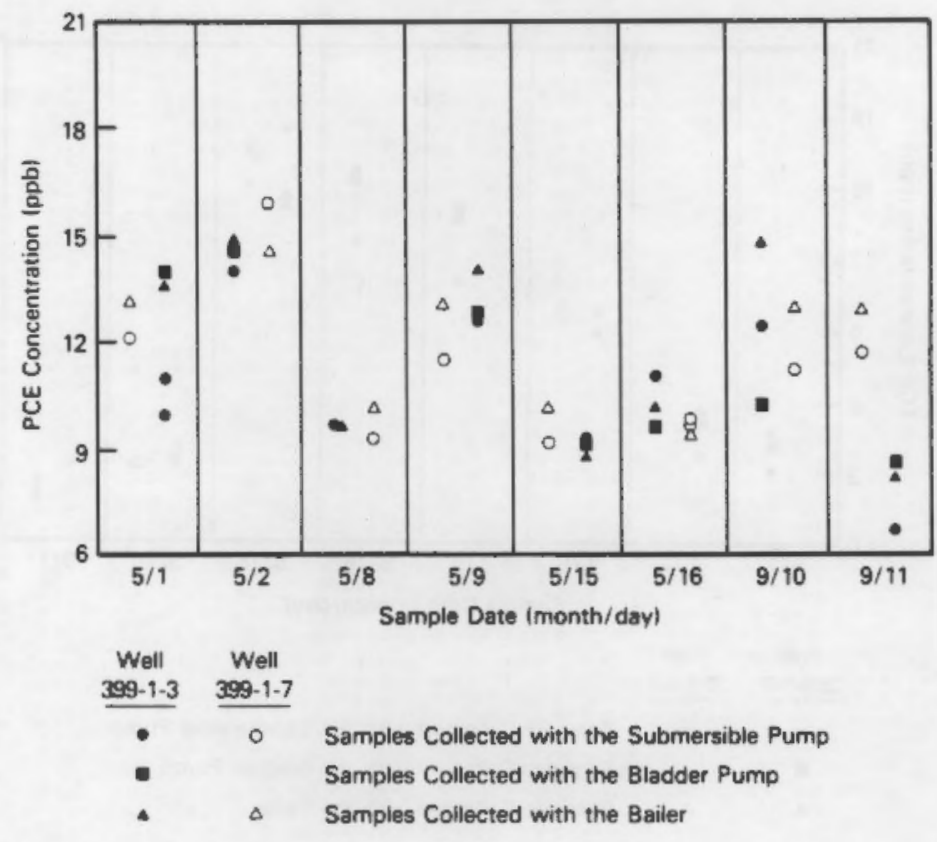

FIGURE 6. PCE Concentrations for Each Sampling Date, Well, and Pump

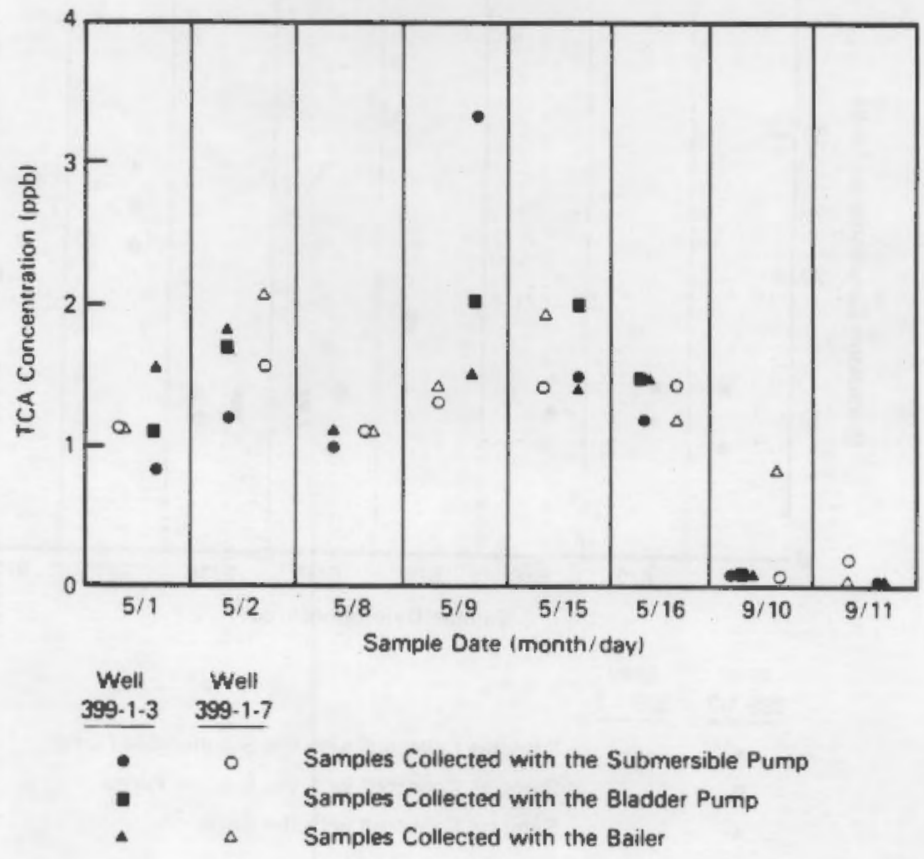

FIGURE 7. TCA Concentrations for Each Sampling Date, Well, and Pump 


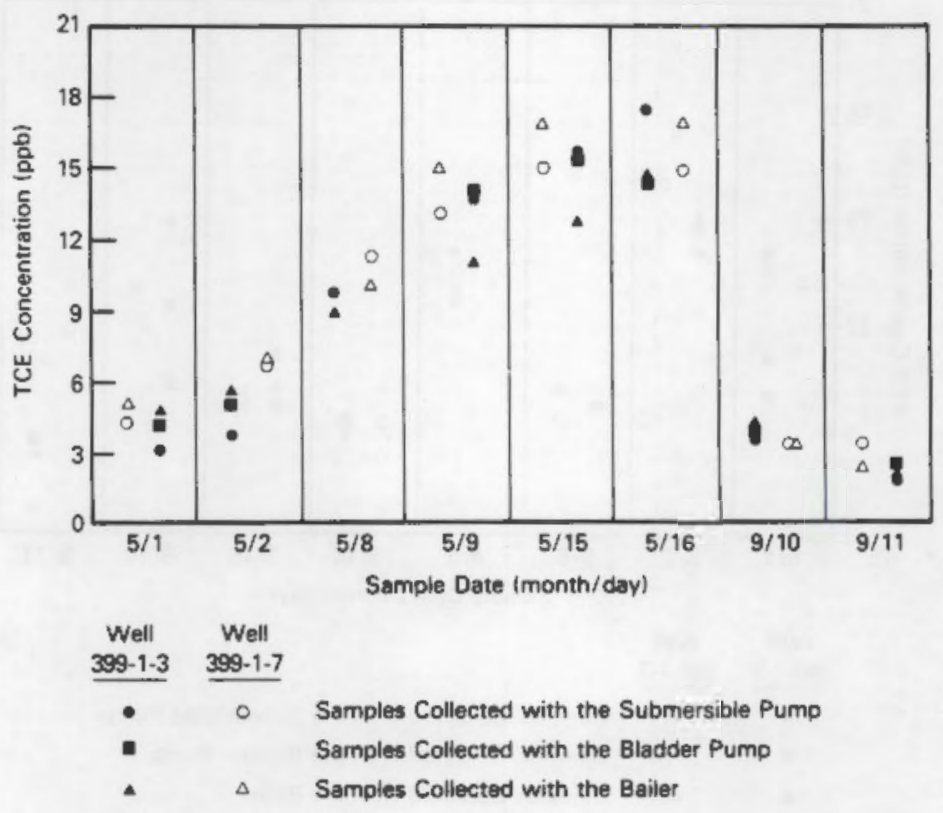

FIGURE 8. TCE Concentrations for Each Sampling Date, We11, and Pump

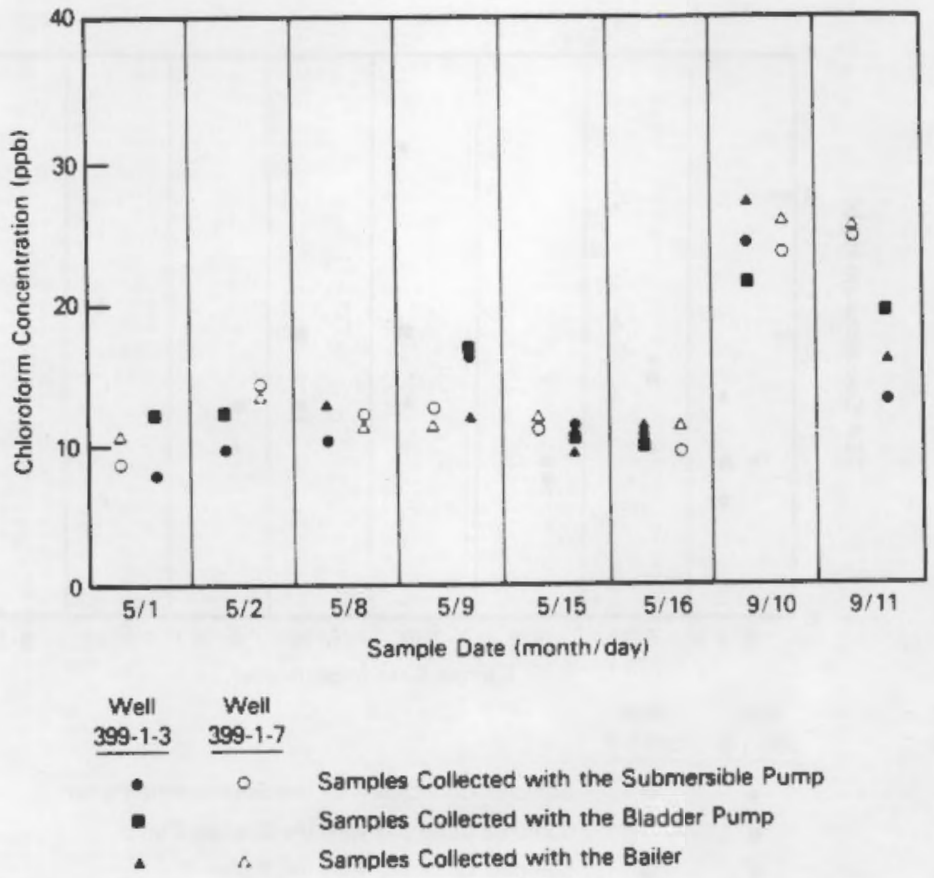

FIGURE 9. Chloroform Concentrations for Each Sampling Date, We11, and Pump 
TABLE 5. Analysis of Variance Results

\begin{tabular}{|c|c|c|c|}
\hline \multirow[b]{2}{*}{ Sources of Variation } & \multicolumn{3}{|c|}{ Data Set (P-Values) } \\
\hline & Subset-1 & Subset-2 & Subset-3 \\
\hline \multicolumn{4}{|l|}{ PCE } \\
\hline Well Type & 0.31 & 0.57 & 0.57 \\
\hline Pump Type & 0.15 & 0.05 & 0.07 \\
\hline Well/Pump & 0.76 & 0.76 & 0.66 \\
\hline Sample Date & 0.00 & 0.00 & 0.00 \\
\hline Water Table Elevation & 0.63 & 0.83 & 0.85 \\
\hline \multicolumn{4}{|l|}{ TCA } \\
\hline Well Type & 0.66 & 0.72 & 0.82 \\
\hline Pump Type & 0.69 & 0.71 & 0.74 \\
\hline Well/Pump & 0.47 & 0.51 & 0.48 \\
\hline Sample Date & 0.01 & 0.02 & 0.08 \\
\hline Water Table Elevation & 0.18 & 0.22 & 0.25 \\
\hline \multicolumn{4}{|l|}{ TCE } \\
\hline Well Type & 0.09 & 0.17 & 0.24 \\
\hline Pump Type & 0.58 & 0.66 & 0.71 \\
\hline We11/Pump & 0.12 & 0.11 & 0.13 \\
\hline Sample Date & 0.00 & 0.00 & 0.00 \\
\hline Water Table Elevation & 0.18 & 0.20 & 0.22 \\
\hline \multicolumn{4}{|l|}{ Chloroform } \\
\hline Well Type & 0.06 & 0.61 & 0.67 \\
\hline Pump Type & 0.52 & 0.53 & 0.65 \\
\hline Wel1/Pump & 0.94 & 0.94 & 0.79 \\
\hline Sample Date & 0.00 & 0.00 & 0.00 \\
\hline Water Table Elevation & 0.26 & 0.49 & 0.51 \\
\hline
\end{tabular}

for any of the contaminants. However, the P-values do indicate that sample date was a statistically significant source of variation for all of the contaminants.

To further compare concentrations of PCE, TCA, TCE, and chloroform with each other and with sample date and water table elevation, the data were plotted in a multivariate graph matrix in conjunction with Pearson correlation coefficients $(r)$ (Figure 10). The individual boxes were examined for linear, curvalinear, or cluster patterns which would indicate a correlation between the two variables. Each correlation coefficient summarizes the corresponding data in the graph matrix. Coefficients of 1 or -1 indicate a linear relation- 


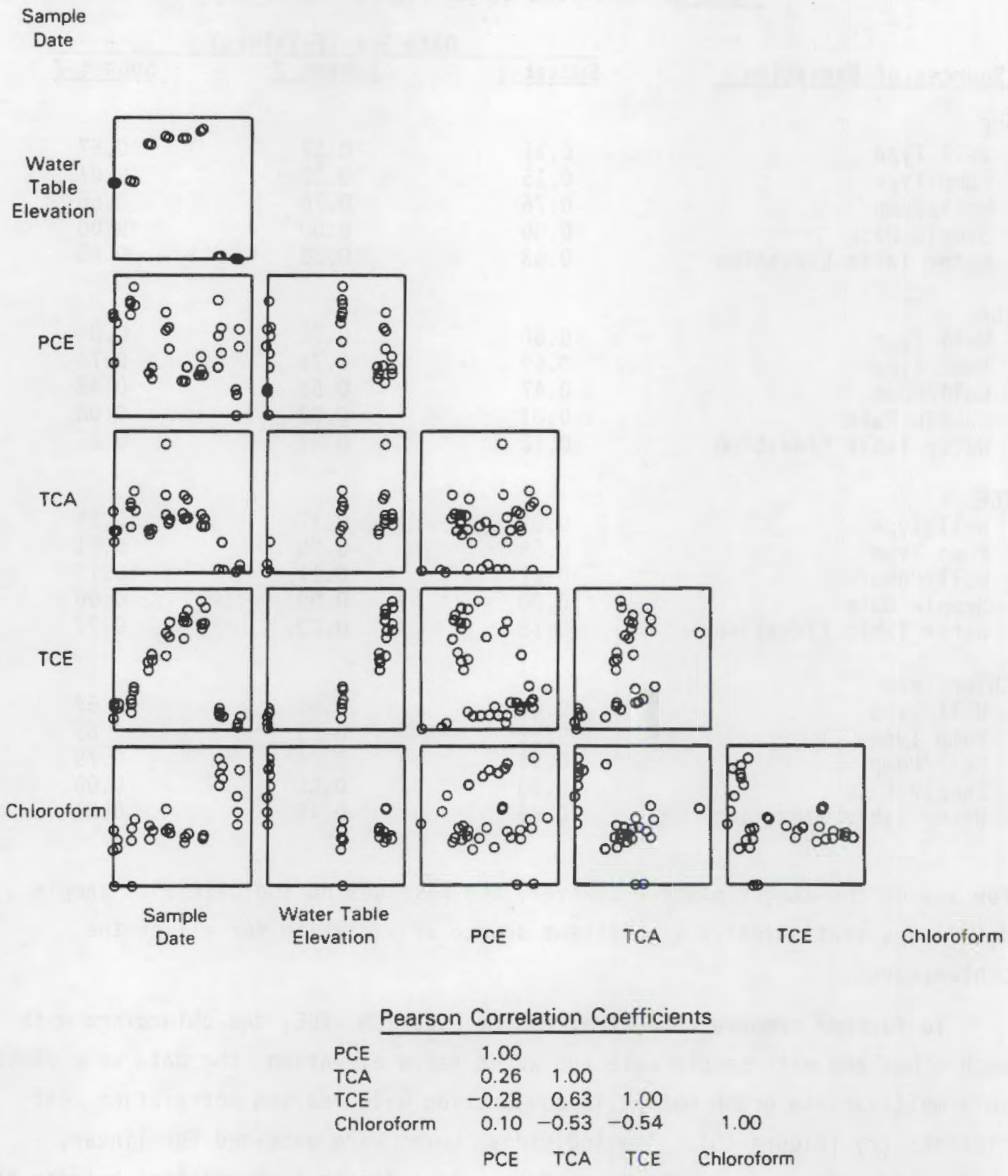

FIGURE 10. Multivariate Graph Matrix With Pearson Correlation Coefficients 
ship between the two variables. These coefficients indicate very little or no linear correlation between PCE concentrations and concentrations of TCA, TCE, and chloroform ( $r=0.26,-0.28$, and 0.10 , respectively, Figure 10$)$. However, the graph matrices indicate correlations between contaminant concentration and sample date and, to a lesser degree, water table elevation. 



\section{REFERENCES}

Barcelona, M. J., et al. 1983. A Guide to the Selection of Materials for Monitoring Well Construction and Ground-Water Sampling. Prepared for U.S. Environmental Protection Agency by Illinois State Water Survey, Champaign, Illinois.

Kempthorne, 0. 1979. The Design and Analysis of Experiments. Krieger Publishing Company, Huntington, New York.

U.S. Environmenta1 Protection Agency (USEPA). 1979. "EPA Methods 601, Purgeable Halocarbons, 624 Purgeables." Federal Register 44(233) (December 3, 1979).

U.S. Environmental Protection Agency (USEPA). 1982. Test Methods for Evaluating Solid Waste; Chapter 3 Draft. SW-846, Office of Solid Waste and Emergency Response, U.S. Environmental Protection Agency, Washington, D.C. 


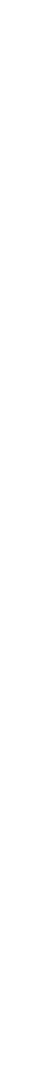




\section{DISTRIBUTION}

No. of

Copies

QFFSITE

10 DOE/Office of Scientific and Technical Information

\section{ONSITE}

4 DOE-Richland Operations office

P. J. Krupin

J. J. Sutey

M. W. Tiernan

M. C. Vargas

2 Westinghouse Hanford Company

L. C. Brown

R. L. Jackson

\section{Pacific Northwest Laboratory}

R. E. Brown

R. W. Bryce

D. S. Daly

J. W. Falco

M. D. Freshley

R. M. Fruland

R. 0. Gilbert

M. J. Graham

R. H. Gray
No. of

Copies

ONSITE

J. M. Hales

M. S. Hanson

P. C. Hays

E. J. Jensen

G. V. Last

T. L. Liikala (10)

P. J. Hitchell

K. B. 01 sen

R. Schalla

R. M. Smith

A. P. Toste

R. E. Wildung

Publishing Coordination (2)

Technical Report Files (5) 
: 